\title{
Evaluation of the Speciation Patterns of Some Heavy Metals along the Major Roads of Owerri Industrial Layout
}

\author{
H. O. Abugu ${ }^{1}$, P.A.C. Okoye ${ }^{2}$ and P. E. Omuku ${ }^{2}$ \\ ${ }^{2}$ (Pure \& Industrial Chemistry Department, Nnamdi Azikiwe University, Awka, Anambra State, Nigeria) \\ ${ }^{I}$ (Department of Quality Control, KSL Investment Ltd Owerri, Imo State, Nigeria)
}

\begin{abstract}
Topsoil samples were collected along the major roads within Owerri industrial layout for the period of April to July. The $\mathrm{pH}$ and the moisture content were determined by $\mathrm{pH}$ meter and difference in wet and dry weight method respectively. The $\mathrm{pH}$ of the soil had a range of 6.1 to 6.7 while moisture content had a range of 5.177 to $13.572 \%$. The highest metal concentration $(832.830 \mathrm{mg} / \mathrm{kg}$ ) was Fe found in the Gmicord Road (RX2), while the metal with the least concentration $(0.067 \mathrm{mg} / \mathrm{kg})$ was $\mathrm{Cd}$. The observed trend in the concentration of the metals was $\mathrm{Fe}>\mathrm{Ca}>\mathrm{Mn}>\mathrm{Zn}>\mathrm{Cr}>\mathrm{Pb}>\mathrm{Ni}>\mathrm{Co}>\mathrm{Cu}>\mathrm{Cd}$. There were no significant differences between the $\mathrm{pH}$ and the concentration of the soil samples. Most of the metals in the soil samples were distributed within the residual fraction which is an indication of geochemical sources.
\end{abstract}

Key Words: Bioavailability, Concentration, Metal, Speciation, Soil.

\section{Introduction}

Human evolution has led to immense scientific and technological progress. Global development (industrialization), however, raises new challenges, especially in the field of environmental protection and conservation [1]. Nearly every government around the world advocates for an environment free from harmful contamination for their citizens. However, the demand for a country's economic, agriculture and industrial development outweigh the demand for a safe, pure and natural environment. Ironically, it is the economic, agricultural and industrial developments that are often linked to polluting the environment [2]. Since the beginning of the industrial revolution, soil pollution by toxic metals has increased dramatically. According to report, about $90 \%$ of the anthropogenic emissions of heavy metals have occurred since 1900AD [3]; it is now well recognized that human activities lead to a substantial accumulation of metals in soils on a global scale. A number of chemicals, heavy metals and other industrial wastes have resulted in significant discharge of industrial effluents into the nearby water bodies and soils and environment at large. These effluents which contain toxic metals or substances are released into the environment which contributes to a variety of toxic effects on living organisms in the food chain by bioaccumulation and bio-magnification. Heavy metals, such as cadmium, copper, lead, chromium, zinc, and nickel are important environmental pollutants, particularly in areas with high anthropogenic pressure [4] such as Owerri industrial layout. The soil has been traditionally the site for disposal for most of the metal wastes which need to be treated. Sources of anthropogenic metal contamination include industrial effluents, fuel production, mining, smelting processes, military operations utilization of agricultural chemicals, small-scale industrial (including battery production, metal products, metal smelting and cable coating industries) brick kilns and coal combustion [5]. One of the prominent sources contributing to increased load of soil contamination is disposal of municipal waste. These wastes are either dumped on roadsides or used as landfills, while sewage is used for irrigation. These wastes, although useful as a source of nutrients, are also sources of carcinogens and toxic metals.

Around the world several studies have evaluated the metal concentration in the soils $[6,7,8,9,10]$. In Owerri industrial layout, such studies are non-existent to date and therefore, very little are known about the distribution of such elements. At present, it is widely recognized that the distribution, mobility and bioavailability of heavy metals and radionuclide in the environment depends not only on their total concentration but also on the association form in the solid phase to which they are bound. Some variations of the chemical or physical conditions in the environment can accelerate to some extent the release of toxic metals into it, thus causing contamination.

Bioavailability of metals depends greatly on the characteristics of the particle surface, on the kind of strength of the bond and on the properties of the solution in contact with the solid samples. Metal ions in soils and sediments are partitioned between the different phase's present i.e. organic matter, oxyhydoxides of iron, aluminum and manganese, phyllosilicate minerals, carbonates and sulfides. In addition, metal ions are retained on these solid phases by different mechanisms (ion exchange, outer and inner-sphere surface complexation (adsorption), precipitation or co-precipitation). Sediment samples have been found as a carrier of most metals and some elements may be recycled through biological and chemical reactions within the water column. In soil, 
there is a concern to know the metal bioavailability and toxicity to plants, animals and man, the efficiency of the soil as a sink for metals and the potential capacity of a metal to be mobilized from the soil [11].

Natural and anthropogenic environmental changes greatly influence the behaviour of metallic pollutants as the association form in which they occur can be changed. Such external influences can include $\mathrm{pH}$, temperature, redox potential, organic matter decomposition, leaching and ion exchange processes and microbial activities. Thus, the exchangeable fractions corresponds to the form of metals that is most available for plant uptake and can be released by merely changing the ionic strength of the medium, the metal content bound to carbonates is sensitive to $\mathrm{pH}$ changes and can become mobilisable when $\mathrm{pH}$ is lowered. The metal fraction bound to Fe-Mn oxides and organic matter can be mobilized with increasing, reducing or oxidizing conditions in the environment. Finally the metal fractions associated with the residual fraction e.g. silicate can only be mobilized as a result of weathering which can only cause long term effects [12].

\section{Materials And Methods}

Soil samples were collected in the vicinity of Owerri Industrial layout between April and July. The sampling site comprised of five major roads, Raycon road (road 1), Gmicord road (road 2), Coca-cola road (road 3), Modern Home Aluminum road (road 4) and Assumpta Press road (road 5) covering the whole length of the area. A total of 5 samples were collected from each road and merged to form a composite sample, a representative of each road using a plastic scoop into a polythene bag well labelled. The sampling site is surrounded by industries. A residential estate (Graceland/Egbeada Estate) is located north - east of the estate. Also to the south - east of the industrial layout is located another estate (Umuguma Housing Estate) and on the north - east is a highway (Onitsha - Owerri Road).

In the laboratory, samples were dried at room temperature and sieved through a $200 \mathrm{mesh}$ before analysis. Drying sediments at higher temperature was avoided to ensure that organic matter content and the metal binding properties of the sediments remained intact. Care was also taken while sieving the sediments to prevent excess loss of the fine particles. All chemicals and acids used were of Analytical Reagent Grade (ARG), and were used without further purification.

\subsection{Procedure for Moisture Content Determination}

The moisture content of the samples was determined using the dry-weight-difference method.

\subsection{Procedure for $\mathrm{pH}$ Determination}

$5 \mathrm{~g}$ of the soil sample was weighed into $250 \mathrm{ml}$ Beaker and $20 \mathrm{ml}$ of deionized water added. It was agitated for about 20minutes and allowed to equilibrate. Finally, a standardized $\mathrm{pH}$ meter was used to read the $\mathrm{pH}$ by dipping the electrode into the $250 \mathrm{ml}$ Beaker containing the solution.

\subsection{Procedure for Determination of Total Metal Content}

About $5 \mathrm{~g}$ of the soil sample was weighed into sample rubber and $5 \mathrm{ml}$ of Hydrofluoric acid (HF) added. Also $10 \mathrm{ml}$ Aqua Regia was added and the mixture heated over water bath for 1hour, 30minutes. Then, it was allowed to cool. The process was repeated again and $20 \mathrm{ml}$ boric acid was added. Thereafter, the solution was filtered and made-up to $50 \mathrm{ml}$ with deionized water. Finally, analysis of the extracts was carried out by Flame Atomic Absorption Spectrometry (Analyst 200).

\subsection{Sequential Extraction}

Sequential extraction protocol for analysis of heavy metal speciation in soil and sediments (modified from Tessier et al., 1979) were used to establish the association of the total concentration of the metals in the soil samples with their contents in the water soluble, exchangeable, carbonate, reducible (Fe/Mn oxide), oxidisable (organic and sulfide bound) and residual fraction [13].

\section{Results And Discussion}

The moisture contents and the $\mathrm{pH}$ of the various soil samples collected from the five major roads are as shown below (Table 1). The $\mathrm{pH}$ of the soil is an important parameter that directly influences mineral mobility. The soil $\mathrm{pH}$ of the sampling sites varied on the average from 6.1 to 6.7 in water indicating of slight acidity to neutrality. The moisture contents fell within the range of $5.177 \%$ to $13.572 \%$. Looking at table 1 , it showed that sample RX1 - RX5 had relatively low values of moisture contents. 
TABLE 1: Percentage Moisture Content and the $\mathrm{pH}$ of the Soil Samples.

\begin{tabular}{|l|l|l|}
\hline Sample code & \% Moisture Content & $\mathrm{pH}$ \\
\hline R1X & 5.177 & 6.6 \\
\hline R2X & 5.398 & 6.1 \\
\hline R3X & 6.099 & 6.4 \\
\hline R4X & 6.084 & 6.3 \\
\hline R5X & 13.572 & 6.7 \\
\hline
\end{tabular}

NOTE: R is referring to as road were the sample was collected, Numbers $1-5$ represent the road numbers, $\mathrm{X}$ means the topsoil sample

TABLE 2: Total Metal Concentration (mg/kg).

\begin{tabular}{|c|c|c|c|c|c|c|c|c|c|c|c|c|}
\hline $\begin{array}{l}\text { Samp } \\
\text { le } \\
\text { code }\end{array}$ & $\mathrm{Cu}$ & $\mathrm{Ca}$ & $\mathrm{Mn}$ & $\mathrm{Pb}$ & $\mathrm{Ni}$ & $\mathrm{Fe}$ & $\mathrm{Co}$ & $\mathrm{Zn}$ & $\mathrm{Cr}$ & $\mathrm{Cd}$ & Total & Mean \\
\hline RX1 & $\begin{array}{l}0.422 \\
\pm 0.0 \\
11 \\
\end{array}$ & $\begin{array}{l}4.880 \\
\pm 0.0 \\
12 \\
\end{array}$ & $\begin{array}{l}3.135 \\
\pm 0.0 \\
16 \\
\end{array}$ & $\begin{array}{l}1.004 \\
\pm 0.0 \\
01 \\
\end{array}$ & $\begin{array}{l}1.582 \\
\pm 0.006\end{array}$ & $\begin{array}{l}4.100 \\
\pm 0.002\end{array}$ & $\begin{array}{l}1.053 \\
\pm 0.004\end{array}$ & $\begin{array}{l}1.813 \\
\pm 0.006\end{array}$ & $\begin{array}{l}2.911 \\
\pm 0.0 \\
11 \\
\end{array}$ & $\begin{array}{l}0.123 \\
\pm 0.0 \\
14 \\
\end{array}$ & 21.023 & $\begin{array}{l}2.102 \\
3\end{array}$ \\
\hline RX2 & $\begin{array}{l}0.292 \\
\pm 0.0 \\
03\end{array}$ & $\begin{array}{l}6.226 \\
\pm 0.1 \\
18\end{array}$ & $\begin{array}{l}3.640 \\
\pm 0.0 \\
69\end{array}$ & $\begin{array}{l}1.041 \\
\pm 0.0 \\
07\end{array}$ & $\begin{array}{l}1.274 \\
\pm 0.020\end{array}$ & $\begin{array}{l}832.83 \\
0 \\
\pm 0.038\end{array}$ & $\begin{array}{l}1.158 \\
\pm 0.065\end{array}$ & $\begin{array}{l}2.709 \\
\pm 0.012\end{array}$ & $\begin{array}{l}1.392 \\
\pm 0.0 \\
11\end{array}$ & $\begin{array}{l}0.139 \\
\pm 0.0 \\
05\end{array}$ & $\begin{array}{l}850.66 \\
1\end{array}$ & $\begin{array}{l}85.06 \\
6\end{array}$ \\
\hline RX3 & $\begin{array}{l}0.357 \\
\pm 0.0 \\
02 \\
\end{array}$ & $\begin{array}{l}2.672 \\
\pm 0.0 \\
07 \\
\end{array}$ & $\begin{array}{l}2.791 \\
\pm 0.0 \\
45 \\
\end{array}$ & $\begin{array}{l}0.482 \\
\pm 0.0 \\
08 \\
\end{array}$ & $\begin{array}{l}0.734 \\
\pm 0.009\end{array}$ & $\begin{array}{l}350.07 \\
0 \\
\pm 0.196\end{array}$ & $\begin{array}{l}0.583 \\
\pm 0.004\end{array}$ & $\begin{array}{l}1.602 \\
\pm 0.006\end{array}$ & $\begin{array}{l}0.858 \\
\pm 0.0 \\
32 \\
\end{array}$ & $\begin{array}{l}0.067 \\
\pm 0.0 \\
03 \\
\end{array}$ & $\begin{array}{l}360.66 \\
1\end{array}$ & $\begin{array}{l}36.02 \\
2\end{array}$ \\
\hline RX4 & $\begin{array}{l}0.663 \\
\pm 0.0 \\
06\end{array}$ & $\begin{array}{l}59.38 \\
8 \\
\pm 0.0 \\
02 \\
\end{array}$ & $\begin{array}{l}3.589 \\
\pm 0.0 \\
66\end{array}$ & $\begin{array}{l}4.162 \\
\pm 0.0 \\
06\end{array}$ & $\begin{array}{l}0.980 \\
\pm 0.021\end{array}$ & $\begin{array}{l}750.21 \\
0 \\
\pm 0.152\end{array}$ & $\begin{array}{l}0.931 \\
\pm 0.013\end{array}$ & $\begin{array}{l}2.730 \\
\pm 0.005\end{array}$ & $\begin{array}{l}1.447 \\
\pm 0.0 \\
18\end{array}$ & $\begin{array}{l}0.627 \\
\pm 0.0 \\
19\end{array}$ & $\begin{array}{l}824.72 \\
7\end{array}$ & $\begin{array}{l}82.47 \\
3\end{array}$ \\
\hline RX5 & $\begin{array}{l}0.332 \\
\pm 0.0 \\
01\end{array}$ & $\begin{array}{l}3.220 \\
\pm 0.0 \\
01\end{array}$ & $\begin{array}{l}2.196 \\
\pm 0.0 \\
04\end{array}$ & $\begin{array}{l}0.591 \\
\pm 0.0 \\
41\end{array}$ & $\begin{array}{l}1.349 \\
\pm 0.011\end{array}$ & $\begin{array}{l}4.500 \\
\pm 0.015\end{array}$ & $\begin{array}{l}0.792 \\
\pm 0.002\end{array}$ & $\begin{array}{l}2.510 \\
\pm 0.013\end{array}$ & $\begin{array}{l}4.210 \\
\pm 0.0 \\
13\end{array}$ & $\begin{array}{l}0.090 \\
\pm 0.0 \\
00\end{array}$ & 19.790 & 1.979 \\
\hline Total & 2.066 & $\begin{array}{l}76.38 \\
6\end{array}$ & $\begin{array}{l}15.35 \\
1\end{array}$ & 7.280 & 5.919 & $\begin{array}{l}1941.7 \\
10\end{array}$ & 4.517 & 11.634 & $\begin{array}{l}10.77 \\
8\end{array}$ & 1.046 & $\begin{array}{l}2076.4 \\
26\end{array}$ & \\
\hline Mean & 0.413 & $\begin{array}{l}15.27 \\
7\end{array}$ & 3.070 & 1.456 & 1.184 & $\begin{array}{l}388.34 \\
2\end{array}$ & 0.903 & 2.273 & 2.156 & 0.209 & $\begin{array}{l}415.28 \\
3\end{array}$ & \\
\hline
\end{tabular}

Table 2 and figure 1, indicate the total metal concentration. The result indicated that the occurrence of Fe was at relatively higher concentration $(832.830 \mathrm{mg} / \mathrm{kg})$ in the soil sample $(\mathrm{RX} 2)$. This may be as a result of auto rust, motor spare parts and other human activities found around the industrial layout.

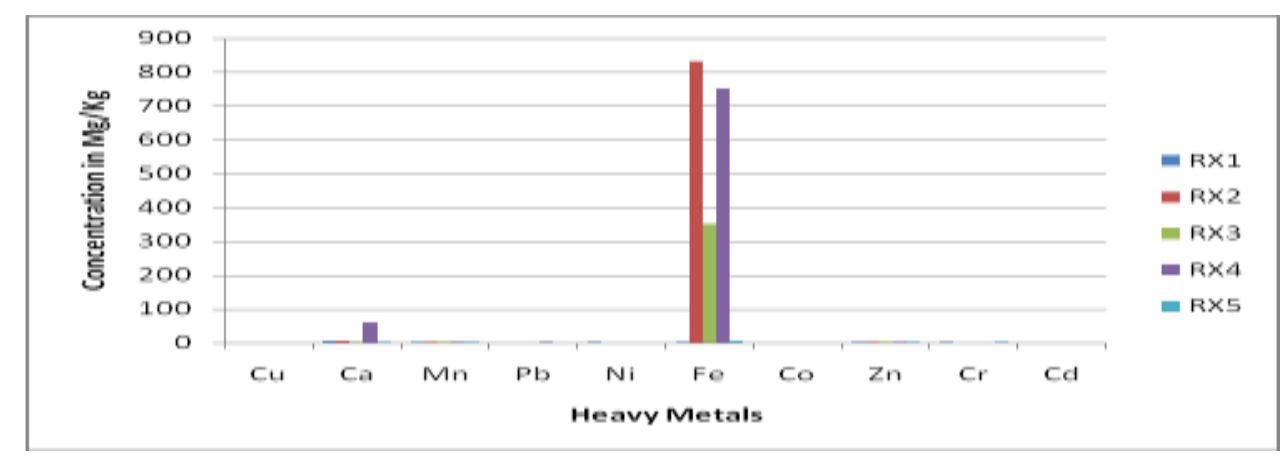

Figure 1: Total Metal Concentration

It also showed that $\mathrm{Cd}$ had the least concentration $(0.067 \mathrm{mg} / \mathrm{kg})$ as found in sample $\mathrm{RX} 3$. The observed trends with various soil samples for the heavy metal concentration are as follows: for $\mathrm{RX} 1$ it was $\mathrm{Ca}>\mathrm{Fe}>\mathrm{Mn}>\mathrm{Cr}>$ $\mathrm{Zn}>\mathrm{Ni}>\mathrm{Co}>\mathrm{Pb}>\mathrm{Cu}>\mathrm{Cd}$, while for $\mathrm{RX} 2$ it was $\mathrm{Fe}>\mathrm{Ca}>\mathrm{Mn}>\mathrm{Zn}>\mathrm{Cr}>\mathrm{Ni}>\mathrm{Co}>\mathrm{Pb}>\mathrm{Cu}>\mathrm{Cd}$.

TABLE 3: Percentage Total Metal Concentration

\begin{tabular}{|l|l|l|l|l|l|l|l|l|l|l|}
\hline $\begin{array}{l}\text { Sample } \\
\text { code }\end{array}$ & $\mathrm{Cu}$ & $\mathrm{Ca}$ & $\mathrm{Mn}$ & $\mathrm{Pb}$ & $\mathrm{Ni}$ & $\mathrm{Fe}$ & $\mathrm{Co}$ & $\mathrm{Zn}$ & $\mathrm{Cr}$ & $\mathrm{Cd}$ \\
\hline $\mathrm{RX} 1$ & 2.007 & 23.217 & 14.912 & 4.776 & 7.525 & 19.502 & 5.009 & 8.624 & 13.847 & 0.585 \\
\hline $\mathrm{RX} 2$ & 0.034 & 0.732 & 0.428 & 0.122 & 0.150 & 97.904 & 0.136 & 0.218 & 0.159 & 0.016 \\
\hline $\mathrm{RX} 3$ & 0.099 & 0.742 & 0.772 & 0.134 & 0.204 & 97.183 & 0.162 & 0.445 & 0.238 & 0.019 \\
\hline RX4 & 0.080 & 7.201 & 0.435 & 0.505 & 0.119 & 90.965 & 0.113 & 0.331 & 0.175 \\
\hline RX5 & 1.678 & 4.036 & 11.097 & 2.986 & 6.817 & 22.739 & 4.002 & 12.683 & 21.273 & 0.455 \\
\hline
\end{tabular}




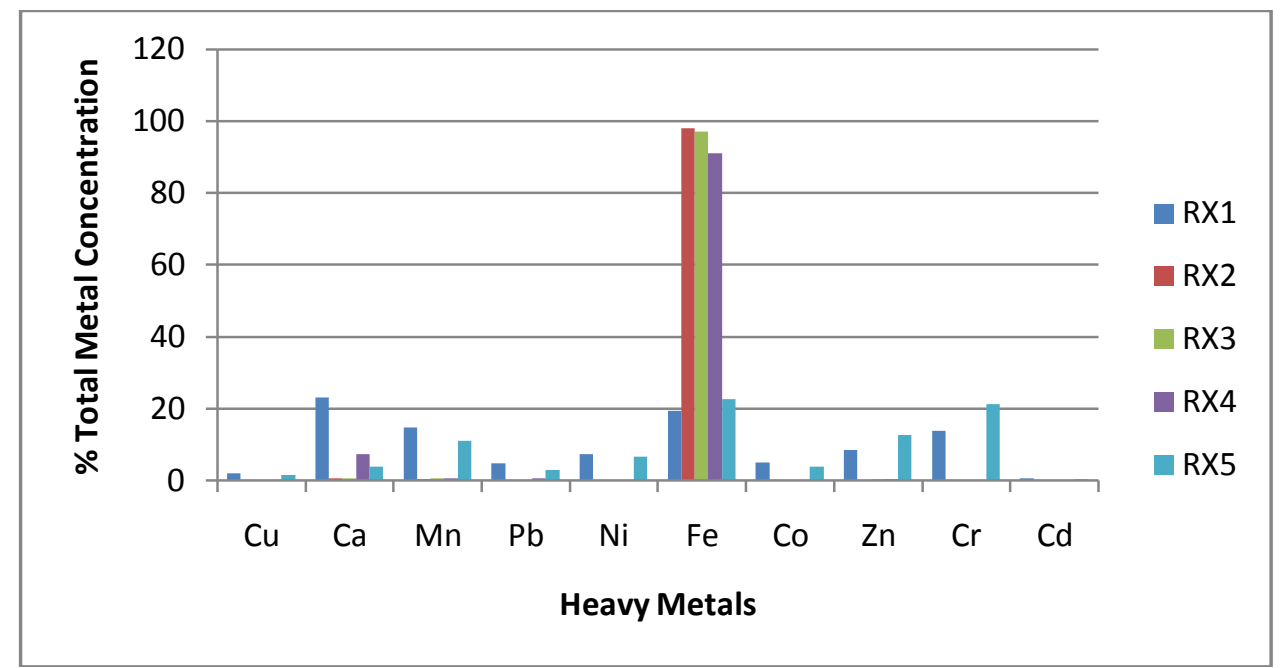

Figure 2: Percentage Total Metal Concentration

The trend $\mathrm{Fe}>\mathrm{Mn}>\mathrm{Ca}>\mathrm{Zn}>\mathrm{Cr}>\mathrm{Ni}>\mathrm{Co}>\mathrm{Pb}>\mathrm{Cu}>\mathrm{Cd}, \mathrm{Fe}>\mathrm{Ca}>\mathrm{Pb}>\mathrm{Mn}>\mathrm{Zn}>\mathrm{Cr}>\mathrm{Ni}>\mathrm{Co}>\mathrm{Cu}>$ $\mathrm{Cd}$ and $\mathrm{Fe}>\mathrm{Cr}>\mathrm{Zn}>\mathrm{Mn}>\mathrm{Ni}>\mathrm{Ca}>\mathrm{Co}>\mathrm{Pb}>\mathrm{Cu}>\mathrm{Cd}$ are for RX3, $\mathrm{RX} 4$ and $\mathrm{RX} 5$ samples respectively. $\mathrm{Cd}$ had the least total concentration and Fe had the highest total concentration except for RX1 where Ca had the maximum value in the soil samples.

TABLE 4: Fractional Concentration of $\mathrm{Cu}$ in the Various Soils Samples $(\mathrm{mg} / \mathrm{kg})$.

\begin{tabular}{|c|c|c|c|c|c|c|c|c|c|c|}
\hline $\begin{array}{l}\text { Sample } \\
\text { code }\end{array}$ & F1 & F2 & F3 & F4 & F5 & F6 & Total & Mean & BAF & $\% \mathrm{BAF}$ \\
\hline RX1 & $\begin{array}{l}0.092 \\
\pm 0.000\end{array}$ & $\begin{array}{l}0.070 \\
\pm 0.001\end{array}$ & $\begin{array}{l}0.166 \\
\pm 0.001\end{array}$ & $\begin{array}{l}0.088 \\
\pm 0.001\end{array}$ & $\begin{array}{l}0.112 \\
\pm 0.002\end{array}$ & $\begin{array}{l}0.315 \\
\pm 0.009\end{array}$ & 0.843 & 0.141 & 0.328 & 38.909 \\
\hline RX2 & $\begin{array}{l}0.651 \\
\pm 0.152\end{array}$ & ND & $\begin{array}{l}0.107 \\
\pm 0.003\end{array}$ & $\begin{array}{l}0.059 \\
\pm 0.001\end{array}$ & $\begin{array}{l}0.150 \\
\pm 0.014\end{array}$ & $\begin{array}{l}0.311 \\
\pm 0.003\end{array}$ & 1.278 & 0.213 & 0.758 & 59.311 \\
\hline RX3 & ND & $\begin{array}{l}0.076 \\
\pm 0.004\end{array}$ & $\begin{array}{l}0.132 \\
\pm 0.000\end{array}$ & $\begin{array}{l}0.079 \\
\pm 0.003\end{array}$ & $\begin{array}{l}0.104 \\
\pm 0.001\end{array}$ & $\begin{array}{l}0.211 \\
\pm 0.003\end{array}$ & 0.602 & 0.100 & 0.208 & 34.551 \\
\hline RX4 & ND & $\begin{array}{l}0.076 \\
\pm 0.002\end{array}$ & $\begin{array}{l}0.193 \\
\pm 0.004\end{array}$ & $\begin{array}{l}0.143 \\
\pm 0.003\end{array}$ & $\begin{array}{l}0.244 \\
\pm 0.004\end{array}$ & $\begin{array}{l}0.086 \\
\pm 0.001\end{array}$ & 0.742 & 0.124 & 0.269 & 36.253 \\
\hline RX5 & $\begin{array}{l}0.099 \\
\pm 0.0012\end{array}$ & $\begin{array}{l}0.023 \\
\pm 0.001\end{array}$ & $\begin{array}{l}0.112 \\
\pm 0.000\end{array}$ & $\begin{array}{l}0.091 \\
\pm 0.002\end{array}$ & $\begin{array}{l}0.149 \\
\pm 0.000\end{array}$ & $\begin{array}{l}0.289 \\
\pm 0.003\end{array}$ & 0.763 & 0.127 & 0.234 & 30.668 \\
\hline Total & 0.842 & 0.245 & 0.708 & 0.460 & 0.759 & 1.212 & 4.366 & 0.728 & 1.795 & 199.692 \\
\hline Mean & 0.164 & 0.049 & 0.142 & 0.092 & 0.152 & 0.242 & 0.841 & 0.140 & 0.355 & 39.938 \\
\hline
\end{tabular}

$F 1=$ Water soluble Fraction, $F 2=$ exchangeable metal fraction, $F 3=$ carbonate fractions, $F 4=$ reducible Fractions, $F 5=$ oxidizable and $F 6=$ residual fractions. $N D=$ not detected .

In the soil samples, much of the copper was associated with residual fractions with a mean value of $0.242 \mathrm{mg} / \mathrm{kg}$ (Table 4). The observed trend in the range of copper concentration in the various fractions was F6 $>$ F1 $>$ F5 $>$ $\mathrm{F} 3>\mathrm{F} 4>\mathrm{F} 2$. Also the trend in the percentage bioavailability of the samples was $\mathrm{RX} 2>\mathrm{RX} 1>\mathrm{RX} 4>\mathrm{RX} 3>$ RX5. The water soluble fractions of samples RX3 and RX4 was at non-detectable level of the FAAS. So also it was for the exchangeable fraction of the RX2 sample. The highest fraction of $\mathrm{Cu}$ was found in sample RX2 $(0.651 \mathrm{mg} / \mathrm{kg})$ in the water soluble fraction $(\mathrm{F} 1)$, and this contributed to the high value of the \% BAF of $\mathrm{Cu}$ $(59.311 \%)$ more than every other sample in the study area.

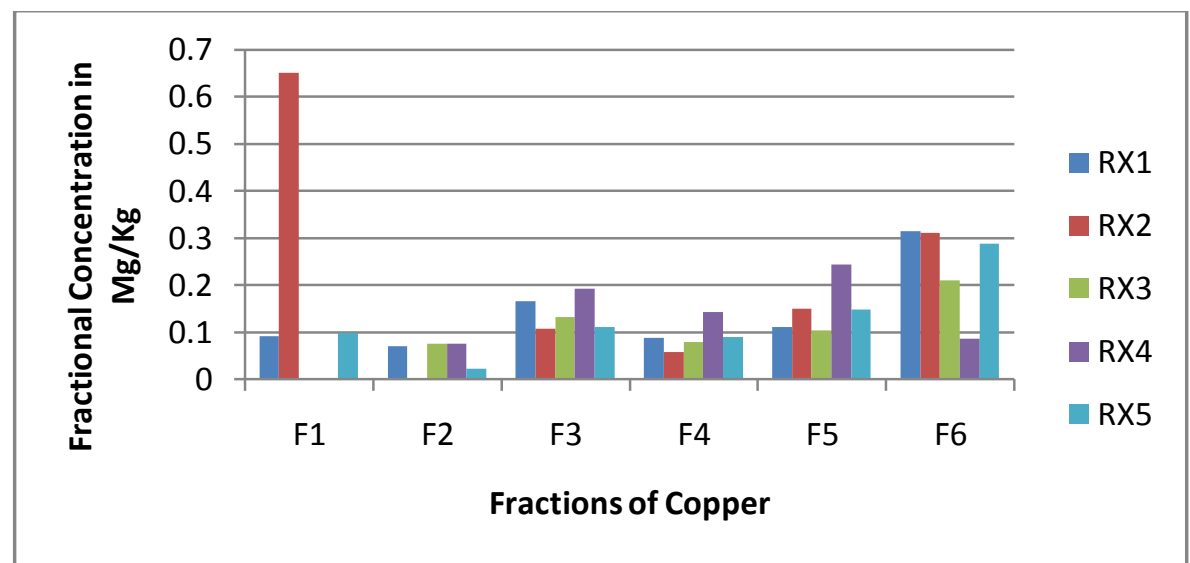

Figure 3: Fractional Concentration of $\mathrm{Cu}$ in the Various Topsoil Samples (mg/kg). 
TABLE 5: Fractional Concentration of $\mathrm{Ca}$ in the Various Soil Samples $(\mathrm{mg} / \mathrm{kg})$.

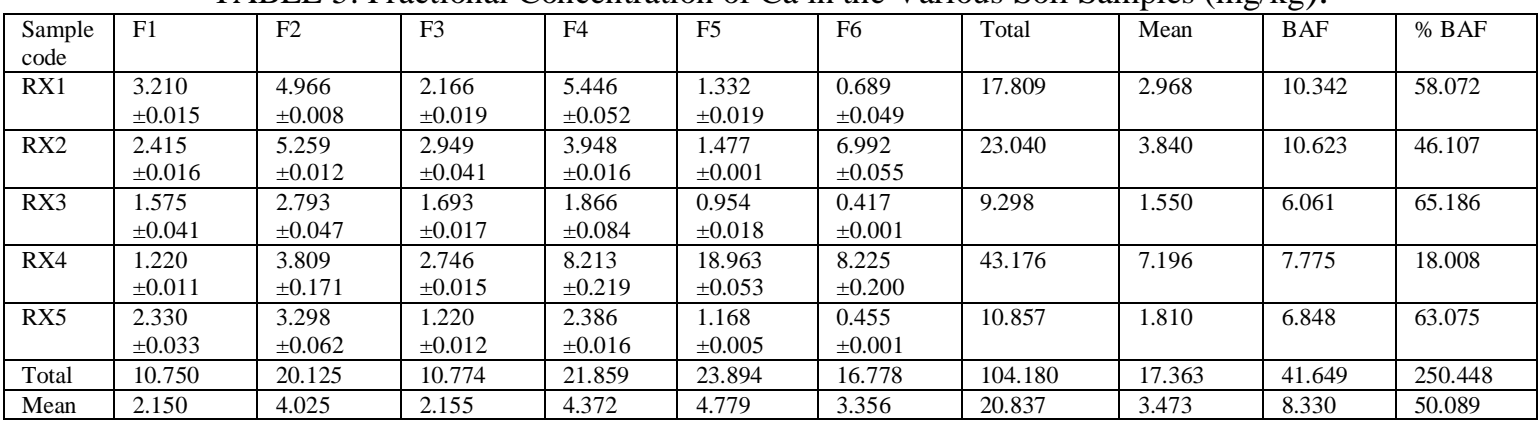

In the soil samples, much of the $\mathrm{Ca}$ was associated with the oxidisable fractions with a mean value of $4.779 \mathrm{mg} / \mathrm{kg}$. The observed trend in the range of Ca concentration in the various fractions was F5 $>\mathrm{F} 4>\mathrm{F} 2>\mathrm{F} 6$ $>\mathrm{F} 3>\mathrm{F} 1$. Also the trend in the percentage bioavailability of the samples was RX3 $>\mathrm{RX} 5>\mathrm{RX} 1>\mathrm{RX} 2>$ RX4. The least fractional concentration of Ca was found in sample RX3 $(0.417 \mathrm{mg} / \mathrm{kg})$ also at the residual fraction.

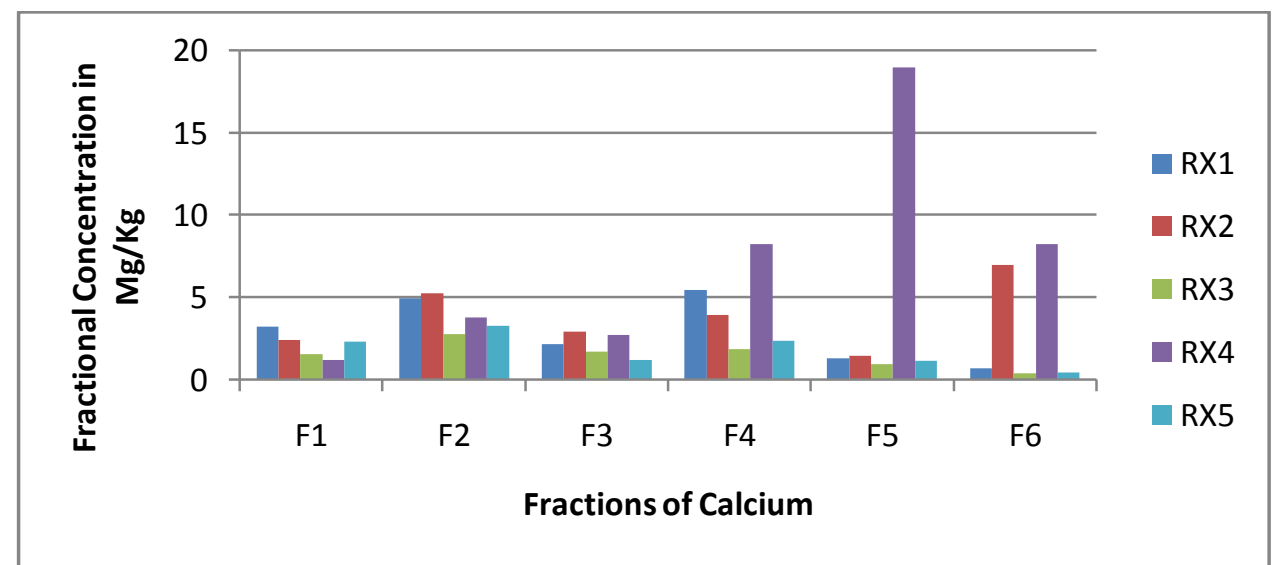

Figure 4: Fractional Concentration of Ca in the Various Soil samples (mg/kg).

From fig. 4, we can see that Road 4 (RX4) recorded the most fractional concentration of Ca $(18.963 \mathrm{mg} / \mathrm{kg})$ at the oxidizable fractions. The mean \% BAF of $\mathrm{Ca}$ is $50.089 \%$, which is slightly above average and it shows that $\mathrm{Ca}$ is potentially bioavailable for organism's uptake in the studied area.

TABLE 6: Fractional Concentration of Mn in the Various Soil Samples (mg/kg).

\begin{tabular}{|l|l|l|l|l|l|l|l|l|l|l|}
\hline $\begin{array}{l}\text { Sample } \\
\text { code }\end{array}$ & F1 & F2 & F3 & F4 & F5 & F6 & Total & Mean & BAF & $\%$ BAF \\
\hline RX1 & 0.221 & 0.681 & 1.021 & 0.886 & 0.945 & 2.311 & 6.065 & 1.010 & 1.923 & 31.707 \\
& \pm 0.013 & \pm 0.003 & \pm 0.000 & \pm 0.012 & \pm 0.005 & \pm 0.019 & & & & \\
\hline RX2 & 0.024 & 0.992 & 1.044 & 0.879 & 1.232 & 2.477 & 6.648 & 1.108 & 2.060 & 30.987 \\
& \pm 0.006 & \pm 0.002 & \pm 0.032 & \pm 0.018 & \pm 0.005 & \pm 0.065 & & & & \\
\hline RX3 & 0.106 & 0.653 & 0.673 & 0.652 & 0.759 & 2.070 & 4.913 & 0.818 & 1.432 & 29.147 \\
& \pm 0.003 & \pm 0.021 & \pm 0.013 & \pm 0.017 & \pm 0.017 & \pm 0.084 & & & & \\
\hline RX4 & 0.139 & 0.388 & 0.856 & 1.047 & 0.849 & 0.465 & 3.744 & 0.624 & 1.383 & 36.939 \\
& \pm 0.005 & \pm 0.005 & \pm 0.031 & \pm 0.023 & \pm 0.018 & \pm 0.007 & & & & \\
\hline RX5 & 0.142 & 0.728 & 1.001 & 0.924 & 0.681 & 1.677 & 5.203 & 0.867 & 1.921 & 36.921 \\
& \pm 0.062 & \pm 0.011 & \pm 0.000 & \pm 0.062 & \pm 0.036 & \pm 0.029 & & & & \\
\hline Total & 0.682 & 3.442 & 4.595 & 4.388 & 4.466 & 9.000 & 26.573 & 4.429 & 8.719 & 165.701 \\
\hline Mean & 0.136 & 0.688 & 0.919 & 0.878 & 0.893 & 1.800 & 5.314 & 0.886 & 1.743 & 33.140 \\
\hline
\end{tabular}

The mean \% BAF of Mn is $33.140 \%$ which is below average and so Mn has a high non-bioavailable fraction in the studied area (Table 6). This is also supported by the observed trend in the concentration of $\mathrm{Mn}$ in the various fractions $-\mathrm{F} 6>\mathrm{F} 3>\mathrm{F} 5>\mathrm{F} 4>\mathrm{F} 2>\mathrm{F} 1$. The trend in the percentage bioavailability of $\mathrm{Mn}$ in the soil samples is $\mathrm{RX} 4>\mathrm{RX} 5>\mathrm{RX} 1>\mathrm{RX} 2>\mathrm{RX} 3$. Much of the Mn fractions were associated with the residual fraction (F6) with mean value of $1.800 \mathrm{mg} / \mathrm{kg}$. 


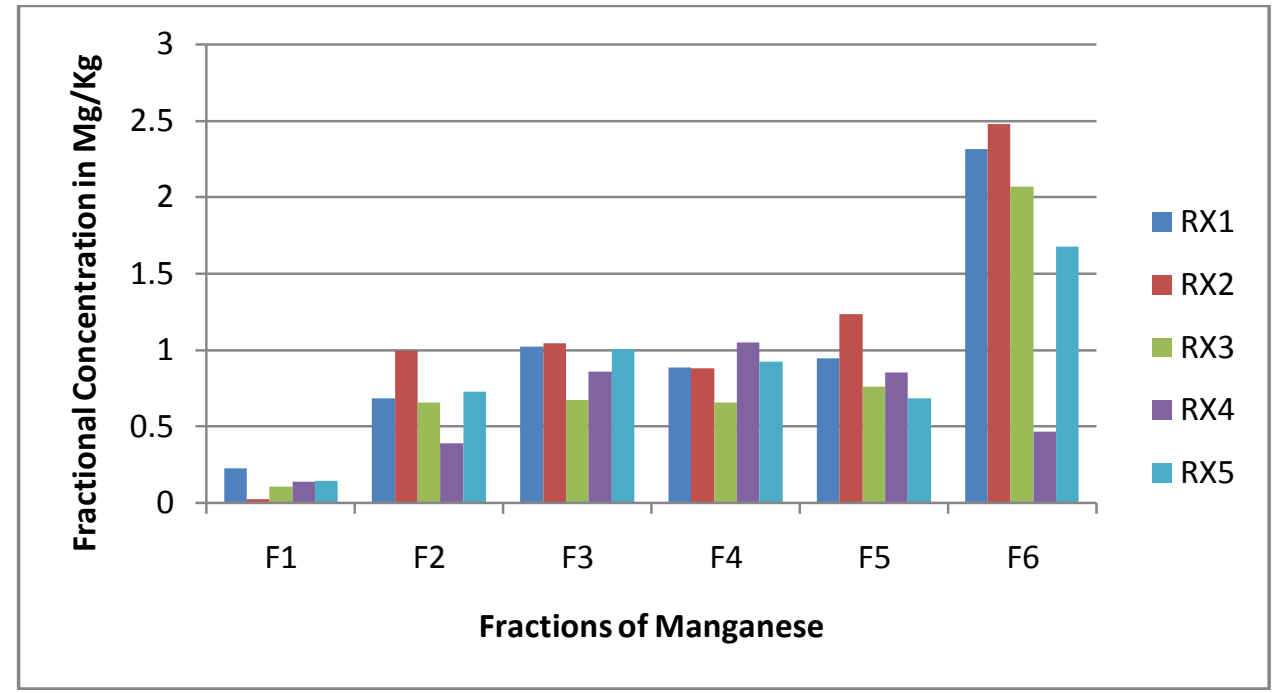

Figure 5: Fractional Concentration of $\mathrm{Mn}$ in the Various Soil Samples (mg/kg).

TABLE 7: Fractional Concentration of $\mathrm{Pb}$ in the Various Soil Samples $(\mathrm{mg} / \mathrm{kg})$.

\begin{tabular}{|c|c|c|c|c|c|c|c|c|c|c|}
\hline $\begin{array}{l}\text { Sample } \\
\text { code }\end{array}$ & F1 & $\mathrm{F} 2$ & F3 & F4 & F5 & F6 & Total & Mean & BAF & $\% \mathrm{BAF}$ \\
\hline RX1 & ND & ND & $\begin{array}{l}0.398 \\
\pm 0.015 \\
\end{array}$ & $\begin{array}{l}0.049 \\
\pm 0.003 \\
\end{array}$ & ND & $\begin{array}{l}0.050 \\
\pm 0.050 \\
\end{array}$ & 0.497 & 0.083 & 0.398 & 80.080 \\
\hline RX2 & ND & ND & $\begin{array}{l}0.207 \\
\pm 0.015\end{array}$ & $\begin{array}{l}0.001 \\
\pm 0.007\end{array}$ & ND & $\begin{array}{l}0.561 \\
\pm 0.004\end{array}$ & 0.769 & 0.154 & 0.207 & 26.918 \\
\hline RX3 & ND & ND & $\begin{array}{l}0.222 \\
\pm 0.006\end{array}$ & ND & ND & $\begin{array}{l}0.226 \\
\pm 0.015\end{array}$ & 0.448 & 0.075 & 0.222 & 49.553 \\
\hline RX4 & ND & $\begin{array}{l}0.002 \\
\pm 0.007\end{array}$ & $\begin{array}{l}0.711 \\
\pm 0.009 \\
\end{array}$ & $\begin{array}{l}0.334 \\
\pm 0.007\end{array}$ & $\begin{array}{l}0.292 \\
\pm 0.027\end{array}$ & ND & 1.339 & 0.223 & 0.112 & 8.364 \\
\hline RX5 & ND & $\begin{array}{l}0.023 \\
\pm 0.002\end{array}$ & $\begin{array}{l}0.538 \\
\pm 0.014\end{array}$ & $\begin{array}{l}0.039 \\
\pm 0.000\end{array}$ & ND & $\begin{array}{l}0.089 \\
\pm 0.006\end{array}$ & 0.689 & 0.115 & 0.561 & 81.422 \\
\hline Total & 0.000 & 0.025 & 2.076 & 0.423 & 0.292 & 0.926 & 3.742 & 0.624 & 2.101 & 246.337 \\
\hline Mean & 0.000 & 0.005 & 0.415 & 0.085 & 0.058 & 0.185 & 0.748 & 0.125 & 0.420 & 49.267 \\
\hline
\end{tabular}

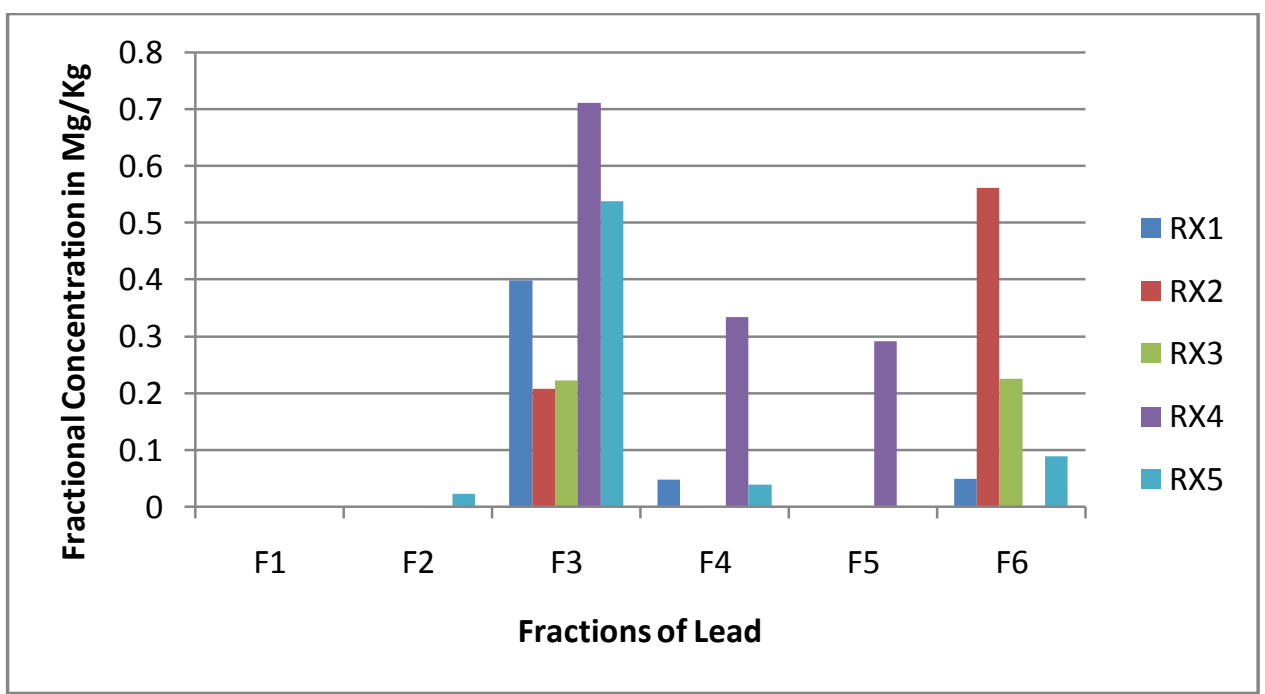

Figure 6: Fractional Concentration of $\mathrm{Pb}$ in the Various Soil Samples ( $\mathrm{mg} / \mathrm{kg})$.

From table 7 much of the $\mathrm{Pb}$ was associated with the carbonate fraction were the mean concentration is $0.415 \mathrm{mg} / \mathrm{kg}$. This is also shown by the observed trend of the various fractions of $\mathrm{Pb}-\mathrm{F} 3>\mathrm{F} 6>\mathrm{F} 4>\mathrm{F} 5>\mathrm{F} 2>$ $\mathrm{F} 1$. $\mathrm{Pb}$ was not detectable by the FAAS on the water soluble fraction. It was detectable at the exchangeable fraction only in samples RX4 and RX5. Also it was not found in sample RX3 on the reducible fraction and in the oxidisable fraction, it was not detectable except for sample RX4 only and on the residual fraction, it was seen in all the samples except for sample RX4. The observed trend in the percentage bioavailable fractions of the samples was RX5 > RX1 > RX3 > RX2 > RX4 (Table 7). Much of the Pb was associated with the carbonate 
bound fraction and is potentially bioavailable in most of the studied area (fig. 6), except for road 2 (RX2) were the $\% \mathrm{BAF}$ was below $50 \%$ in the carbonate bound fraction, but rather higher in the residual fraction.

TABLE 8: Fractional Concentration of $\mathrm{Ni}$ in the Various Soil Samples $(\mathrm{mg} / \mathrm{kg})$.

\begin{tabular}{|l|l|l|l|l|l|l|l|l|l|l|}
\hline $\begin{array}{l}\text { Sample } \\
\text { code }\end{array}$ & F1 & F2 & F3 & F4 & F5 & F6 & Total & Mean & BAF & BAF \\
\hline RX1 & 0.019 & 0.218 & 0.309 & 0.065 & 0.057 & 0.728 & 1.396 & 0.233 & 0.546 & 39.112 \\
& \pm 0.001 & \pm 0.000 & \pm 0.002 & \pm 0.001 & $\begin{array}{l} \pm 0.000 \\
\pm 0.000\end{array}$ & & & \\
\hline RX2 & 0.027 & 0.136 & 0.226 & 0.050 & 0.080 & 0.720 & 1.239 & 0.207 & 0.389 & 31.396 \\
& \pm 0.006 & \pm 0.002 & \pm 0.014 & \pm 0.003 & \pm 0.003 & \pm 0.007 & & & \\
\hline RX3 & 0.016 & 0.125 & 0.245 & 0.048 & 0.044 & 0.506 & 0.984 & 0.164 & 0.386 & 39.228 \\
& \pm 0.001 & \pm 0.001 & \pm 0.006 & \pm 0.000 & \pm 0.000 & \pm 0.001 & & & \\
\hline RX4 & 0.029 & 0.138 & 0.332 & 0.076 & 0.069 & 0.114 & 0.758 & 0.126 & 0.499 & 65.831 \\
& \pm 0.002 & \pm 0.004 & \pm 0.068 & \pm 0.000 & \pm 0.005 & \pm 0.005 & & & \\
\hline RX5 & 0.032 & 0.334 & 0.292 & 0.054 & 0.060 & 0.438 & 1.210 & 0.202 & 0.658 & 54.380 \\
& \pm 0.002 & \pm 0.011 & \pm 0.000 & \pm 0.000 & \pm 0.000 & \pm 0.002 & & & \\
\hline Total & 0.123 & 0.951 & 1.404 & 0.293 & 0.310 & 2.506 & 5.587 & 0.931 & 2.478 & 229.947 \\
\hline Mean & 0.025 & 0.190 & 0.281 & 0.059 & 0.062 & 0.501 & 1.118 & 0.186 & 0.496 & 45.989 \\
\hline
\end{tabular}

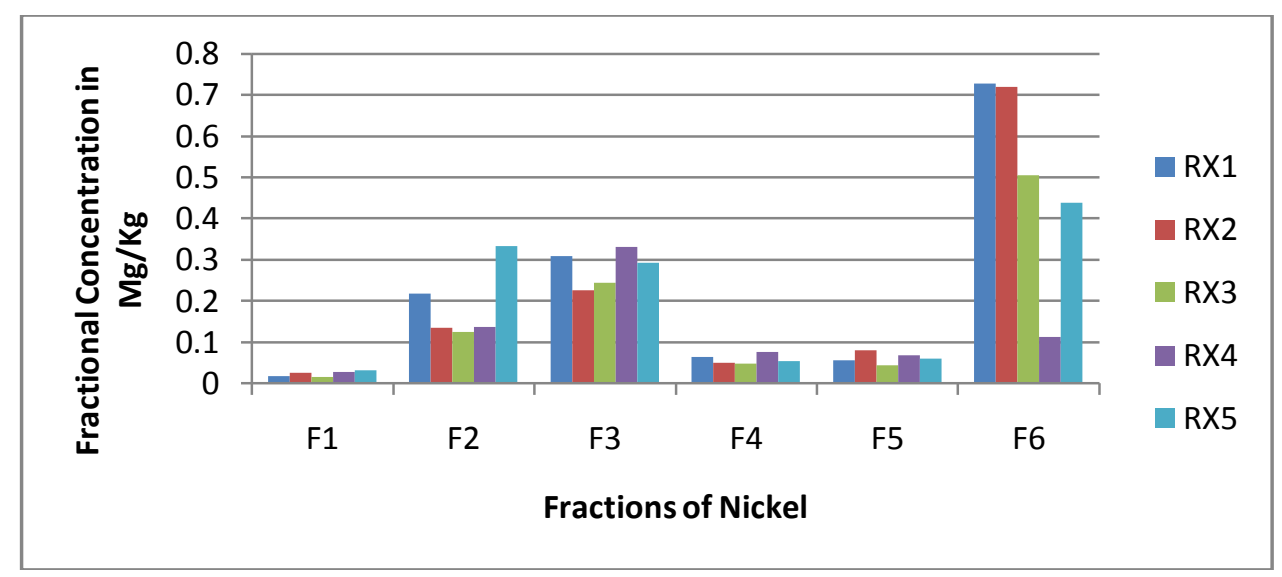

Figure 7: Fractional Concentration of Ni in the Various Soils Samples (mg/kg).

Table 8 represents the various fractions of $\mathrm{Ni}$ in the soil samples. The highest concentration of $\mathrm{Ni}$ in the various samples was recorded in the residual fraction (F6) with a value $0.728 \mathrm{mg} / \mathrm{kg}$ (RX1) and the least was found on sample RX3 in the water soluble fraction with a value of $0.016 \mathrm{mg} / \mathrm{kg}$. The observed trends in the percentage $\mathrm{BAF}$ and the mean concentration of the samples in the fractions are RX4 $>\mathrm{RX} 5>\mathrm{RX} 3>\mathrm{RX} 1>\mathrm{RX} 2$ and F6 $>$ $\mathrm{F} 3>\mathrm{F} 2>\mathrm{F} 5>\mathrm{F} 4>\mathrm{F} 1$ respectively. The bioavailable fraction of $\mathrm{Ni}$ is generally low since the \%BAF of all the samples were below $50 \%$ except for samples of road 4 and 5 .

TABLE 9: Fractional Concentration of Fe in the Various Soil Samples (mg/kg).

\begin{tabular}{|l|l|l|l|l|l|l|l|l|l|l|}
\hline $\begin{array}{l}\text { Sample } \\
\text { code }\end{array}$ & F1 & F2 & F3 & F4 & F5 & F6 & Total & Mean & BAF & $\%$ BAF \\
\hline RX1 & 0.200 & 9.100 & 8.100 & 10.100 & 4.600 \\
& \pm 0.039 & \pm 0.066 & \pm 0.142 & \pm 0.055 & $\begin{array}{l}14.000 \\
\pm 0.039\end{array}$ & 46.100 & 7.683 & 17.400 & 37.744 \\
& ND & 12.380 & 25.431 & 42.924 & $\begin{array}{l}114.618 \\
\pm 0.146\end{array}$ & $\begin{array}{l}27.800 \\
\pm 0.139\end{array}$ & 223.153 & 37.192 & 37.811 & 16.944 \\
& & \pm 0.060 & \pm 0.035 & \pm 0.028 & & & \\
\hline RX3 & ND & 4.242 & 15.090 & 90.741 & 61.215 & 255.360 & 426.648 & 71.100 & 19.332 & 4.531 \\
& & \pm 0.017 & \pm 0.013 & \pm 0.002 & \pm 0.085 & \pm 0.014 & & & \\
\hline RX4 & ND & 14.150 & 20.916 & 109.683 & 76.398 & 10.840 & 231.987 & 38.665 & 35.066 & 15.115 \\
& & \pm 0.094 & \pm 0.058 & \pm 0.090 & \pm 0.062 & \pm 0.457 & & & \\
\hline RX5 & 0.200 & 5.881 & 9.100 & 7.000 & 8.000 & 10.400 & 40.581 & 6.764 & 15.181 & 37.409 \\
& \pm 0.022 & \pm 0.046 & \pm 0.022 & \pm 0.056 & \pm 0.029 & \pm 0.049 & & & \\
\hline Total & 0.400 & 45.753 & 78.637 & 260.448 & 264.831 & 318.400 & 968.469 & 161.412 & 124.790 & 111.743 \\
\hline Mean & 0.080 & 9.151 & 15.727 & 52.090 & 52.966 & 63.680 & 193.694 & 32.282 & 24.958 & 22.349 \\
\hline
\end{tabular}




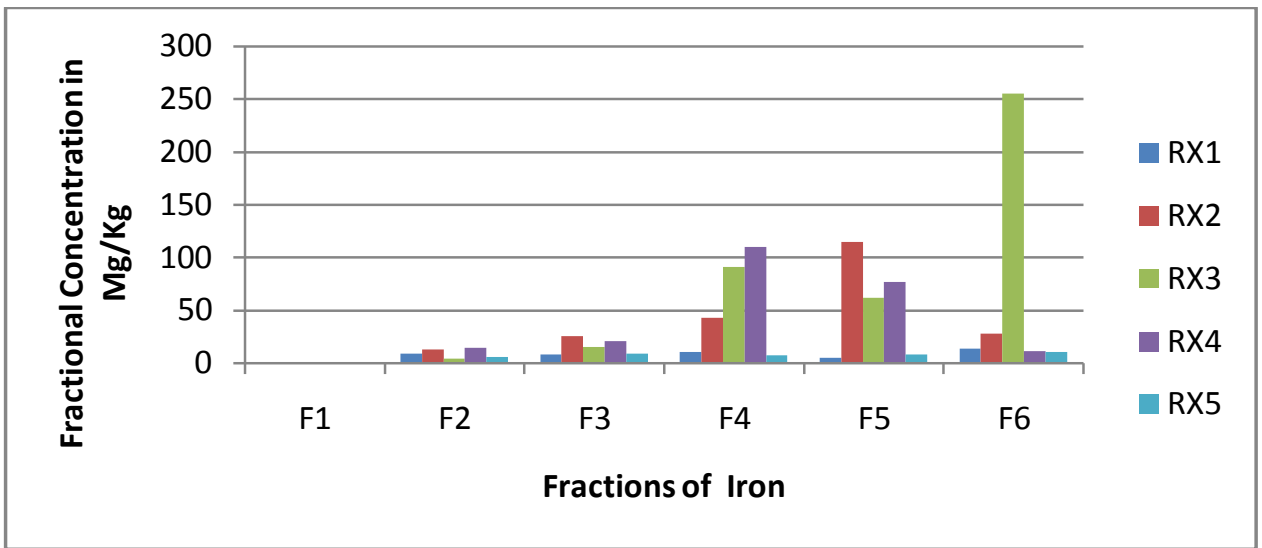

Figure 8: Fractional Concentration of Fe in the Various Soil Samples (mg/kg).

Represented in table 9 is the fractionation pattern of Fe in the soil samples. On the water soluble fraction $\mathrm{Fe}$ was not detectable by the FAAS in all the samples except for samples RX1 and RX5, this lead to low mobility of Fe and its low bioavailability.

TABLE 10: Fractional Concentration of Co in the Various Soil Samples ( $\mathrm{mg} / \mathrm{kg})$.

\begin{tabular}{|l|l|l|l|l|l|l|l|l|l|l|}
\hline $\begin{array}{l}\text { Sample } \\
\text { code }\end{array}$ & F1 & F2 & F3 & F4 & F5 & F6 & Total & Mean & BAF & BAF \\
\hline RX1 & 0.012 & $\begin{array}{l}0.215 \\
\pm 0.005\end{array}$ & $\begin{array}{l}0.226 \\
\pm 0.006\end{array}$ & $\begin{array}{l}0.010 \\
\pm 0.010\end{array}$ & $\begin{array}{l}0.030 \\
\pm 0.003\end{array}$ & $\begin{array}{l}0.556 \\
\pm 0.001\end{array}$ & 1.049 & 0.181 & 0.487 & 44.968 \\
\hline RX2 & ND & $\begin{array}{l}0.091 \\
\pm 0.004\end{array}$ & $\begin{array}{l}0.166 \\
\pm 0.002\end{array}$ & ND & $\begin{array}{l}0.024 \\
\pm 0.004\end{array}$ & $\begin{array}{l}0.639 \\
\pm 0.011\end{array}$ & 0.920 & 0.153 & 0.257 & 27.934 \\
& ND & 0.076 & 6.135 & 0.016 & 0.023 \\
\pm 0.001 & \pm 0.004 & \pm 0.001 & $\begin{array}{l}0.494 \\
\pm 0.004\end{array}$ & 6.744 & 1.124 & 6.211 & 92.097 \\
& & 0.126 & 0.250 & 0.034 & 0.039 & 0.098 & 0.561 & 0.094 & 0.390 & 69.519 \\
\hline RX4 & 0.014 & \pm 0.002 & \pm 0.005 & \pm 0.003 & \pm 0.004 & \pm 0.001 & & & \\
& \pm 0.002 & \pm 0.002 & 0.028 & 0.518 & 0.744 & 0.124 & 0.196 & 26.344 \\
\hline RX5 & ND & 0.010 & 0.186 & 0.002 & \pm 0.005 & & & \\
\hline Total & 0.026 & 0.518 & 6.963 & 0.062 & 0.144 & 2.305 & 10.018 & 1.670 & 7.507 & 260.862 \\
\hline Mean & 0.005 & 0.104 & 1.393 & 0.012 & 0.029 & 0.461 & 2.004 & 0.334 & 1.502 & 52.172 \\
\hline
\end{tabular}

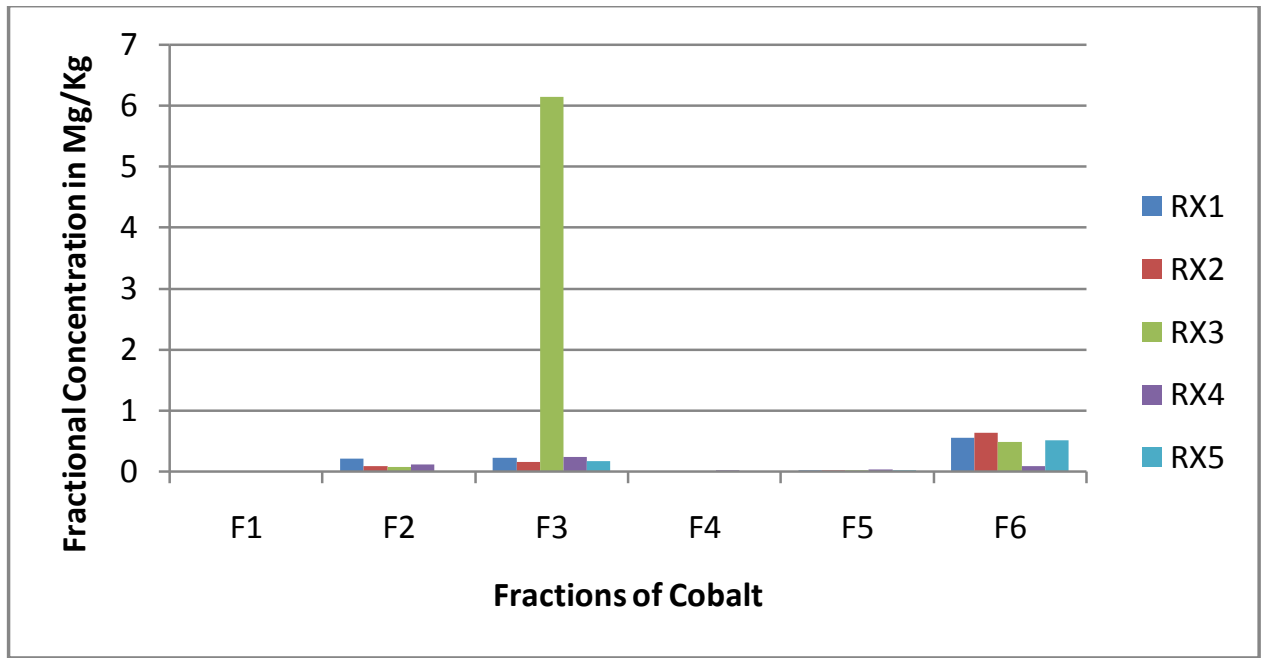

Figure 9: Fractional Concentration of Co in the Various Soil Samples $(\mathrm{mg} / \mathrm{kg})$.

It was most in sample RX3 on the residual fraction $(255.360 \mathrm{mg} / \mathrm{kg})$ while the least value of Fe was found in samples RX1 and RX5 $(0.200 \mathrm{mg} / \mathrm{kg})$ on their water soluble fractions. The observed trend in the percentage BAF of the samples is RX1 > RX5 > RX2 > RX4 > RX3, while that of the mean concentration of their various fractions is F6 $>$ F5 $>$ F4 $>$ F3 $>$ F2 $>$ F1. Since most of the Fe is associated with the residual fraction, it means that it is mainly from geochemical sources.

The observed trend in the mean concentration of the fractions of Co was F3 > F6 > F2 > F5 > F4 > F1 while the trend in the percentage BAF of the samples is RX3 > RX4 > RX1 > RX2 > RX5 (Table 10). Co had its highest concentration in sample RX3 at the reducible fraction $(\mathrm{F} 3)(6.135 \mathrm{mg} / \mathrm{kg})$ and the least value in sample RX5 $(0.002 \mathrm{mg} / \mathrm{kg})$ also at the reducible fraction, but it was undetectable in samples RX2, RX3 and RX5 
in their water soluble fractions (F1) and also in the reducible fraction of sample RX2. The \% bioavailable fraction of Co was considerably high since the mean $\% \mathrm{BAF}$ is $52.172 \%$, though it was low for roads 5 and 2.

TABLE 11: Fractional Concentration of $\mathrm{Zn}$ in the Various Soil Samples (mg/kg).

\begin{tabular}{|l|l|l|l|l|l|l|l|l|l|l|l|}
\hline $\begin{array}{l}\text { Sample } \\
\text { code }\end{array}$ & F1 & F2 & F3 & F4 & F5 & F6 & Total & Mean & BAF & $\%$ BAF \\
\hline RX1 & 0.711 & 0.311 & 0.623 & 0.213 & 0.326 & 6.321 & 8.505 & 1.418 & 1.645 & 19.342 \\
& \pm 0.010 & \pm 0.012 & \pm 0.006 & \pm 0.005 & \pm 0.015 & \pm 0.002 & & & & \\
\hline RX2 & 0.082 & 0.262 & 0.471 & 0.370 & 0.423 & 15.225 & 16.833 & 2.806 & 0.815 & 4.842 \\
& \pm 0.011 & \pm 0.015 & \pm 0.011 & \pm 0.015 & \pm 0.003 & \pm 0.013 & & & & \\
\hline RX3 & 0.103 & 0.249 & 0.538 & 0.454 & 0.437 & 5.208 & 6.989 & 1.164 & 0.890 & 12.734 \\
& \pm 0.005 & \pm 0.002 & \pm 0.011 & \pm 0.011 & \pm 0.008 & \pm 0.015 & & & & \\
\hline RX4 & 0.204 & 0.259 & 1.375 & 0.824 & 0.917 & 0.330 & 3.909 & 0.652 & 1.838 & 47.020 \\
& \pm 0.006 & \pm 0.001 & \pm 0.014 & \pm 0.016 & \pm 0.017 & \pm 0.005 & & & & \\
\hline RX5 & 0.166 & 0.255 & 0.332 & 0.232 & 0.365 & 8.133 & 9.483 & 1.581 & 0.753 & 7.941 \\
& \pm 0.012 & \pm 0.015 & \pm 0.002 & \pm 0.005 & \pm 0.008 & \pm 0.005 & & & & \\
\hline Total & 1.266 & 1.694 & 3.339 & 2.093 & 2.468 & 35.217 & 46.077 & 7.680 & 6.299 & 91.879 \\
\hline Mean & 0.253 & 0.339 & 0.668 & 0.419 & 0.494 & 7.043 & 9.216 & 1536 & 1.260 & 18.376 \\
\hline
\end{tabular}

The fractional concentration of $\mathrm{Zn}$ in the various soil samples represented by table 11 showed that most of the zinc concentration was found in the residual fractions. The mean concentration is $7.043 \mathrm{mg} / \mathrm{kg}$ at the residual fraction and the least was in the water soluble fraction with a value of $0.253 \mathrm{mg} / \mathrm{kg}$.

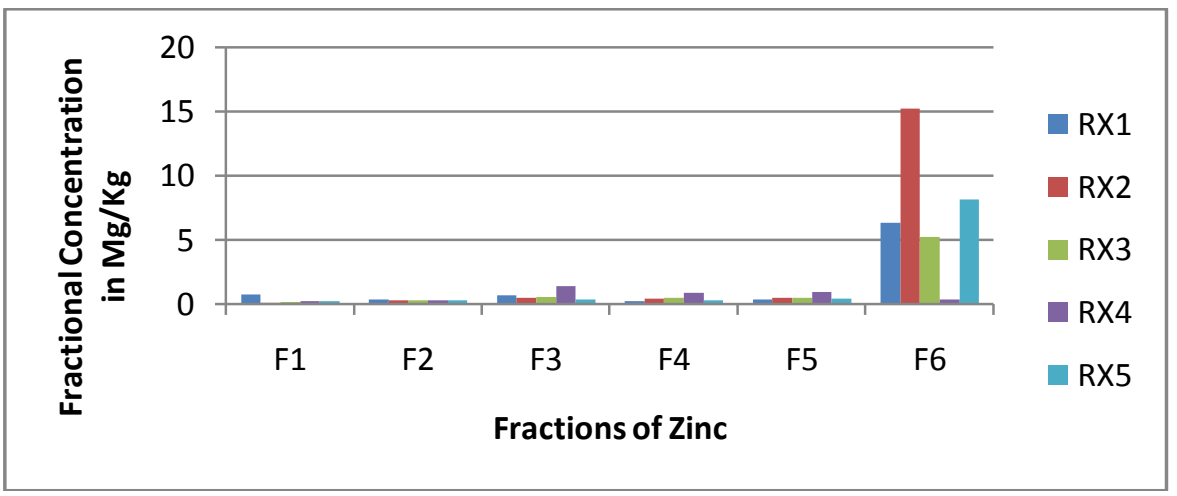

Figure 10: Fractional Concentration of $\mathrm{Zn}$ in the Various Soil Samples (mg/kg).

TABLE 12: Fractional Concentration of $\mathrm{Cr}$ in the Various Soil Samples (mg/kg).

\begin{tabular}{|c|c|c|c|c|c|c|c|c|c|c|}
\hline $\begin{array}{l}\text { Sample } \\
\text { code }\end{array}$ & F1 & F2 & F3 & F4 & F5 & F6 & Total & Mean & BAF & $\begin{array}{l}\% \\
\text { BAF }\end{array}$ \\
\hline RX1 & $\begin{array}{l}0.055 \\
\pm 0.015\end{array}$ & $\begin{array}{l}0.050 \\
\pm 0.001\end{array}$ & $\begin{array}{l}0.160 \\
\pm 0.006\end{array}$ & $\begin{array}{l}0.210 \\
\pm 0.004\end{array}$ & $\begin{array}{l}0.271 \\
\pm 0.011\end{array}$ & $\begin{array}{l}0.623 \\
\pm 0.018\end{array}$ & 1.369 & 0.228 & 0.265 & 19.357 \\
\hline RX2 & $\begin{array}{l}0.018 \\
\pm 0.025\end{array}$ & $\begin{array}{l}0.060 \\
\pm 0.000\end{array}$ & $\begin{array}{l}0.154 \\
\pm 0.008\end{array}$ & $\begin{array}{l}0.141 \\
\pm 0.003\end{array}$ & $\begin{array}{l}0.305 \\
\pm 0.020\end{array}$ & $\begin{array}{l}0.874 \\
\pm 0.014\end{array}$ & 1.552 & 0.259 & 0.232 & 14.948 \\
\hline RX3 & $\begin{array}{l}0.027 \\
\pm 0.016\end{array}$ & $\begin{array}{l}0.070 \\
\pm 0.022\end{array}$ & $\begin{array}{l}0.147 \\
\pm 0.021\end{array}$ & $\begin{array}{l}0.240 \\
\pm 0.011\end{array}$ & $\begin{array}{l}0.167 \\
\pm 0.000\end{array}$ & $\begin{array}{l}0.643 \\
\pm 0.000\end{array}$ & 1.294 & 0.216 & 0.244 & 18.856 \\
\hline RX4 & $\begin{array}{l}0.040 \\
\pm 0.003\end{array}$ & $\begin{array}{l}0.103 \\
\pm 0.004\end{array}$ & $\begin{array}{l}0.170 \\
\pm 0.026\end{array}$ & $\begin{array}{l}0.311 \\
\pm 0.010\end{array}$ & $\begin{array}{l}0.245 \\
\pm 0.003\end{array}$ & $\begin{array}{l}0.103 \\
\pm 0.017\end{array}$ & 0.972 & 0.162 & 0.313 & 32.202 \\
\hline RX5 & $\begin{array}{l}0.010 \\
\pm 0.000\end{array}$ & $\begin{array}{l}0.011 \\
\pm 0.002\end{array}$ & $\begin{array}{l}0.110 \\
\pm 0.009\end{array}$ & $\begin{array}{l}0.189 \\
\pm 0.016\end{array}$ & $\begin{array}{l}0.266 \\
\pm 0.008\end{array}$ & $\begin{array}{l}0.682 \\
\pm 0.003\end{array}$ & 1.268 & 0.211 & 0.131 & 10.331 \\
\hline Total & 0.150 & 0.294 & 0.741 & 1.091 & 1.254 & 2.925 & 6.455 & 1.076 & 1.185 & 95.694 \\
\hline Mean & 0.030 & 0.059 & 0.148 & 0.218 & 0.251 & 0.585 & 1.291 & 0.215 & 0.237 & 19.139 \\
\hline
\end{tabular}

The observed trend in the percentage BAF in the various samples is $\mathrm{RX} 4>\mathrm{RX} 1>\mathrm{RX} 3>\mathrm{RX} 5>\mathrm{RX} 2$ while the trend for the mean fractional concentration is F6 > F3 > F5 > F4 > F2 > F1. Generally the \%BAF of Zn in the samples was low and so led to a mean \%BAF of $18.376 \%$. Figure 10 shows the speciation pattern of $\mathrm{Zn}$ in the various fractions of the soil samples and it showed that the residual fraction had the most occurrences.

In table 12, the highest fractional concentration of $\mathrm{Cr}$ (mean $0.585 \mathrm{mg} / \mathrm{kg}$ ) is found in the residual fraction. The least mean concentration was found in the water soluble fraction $(0.030 \mathrm{mg} / \mathrm{kg})$. 


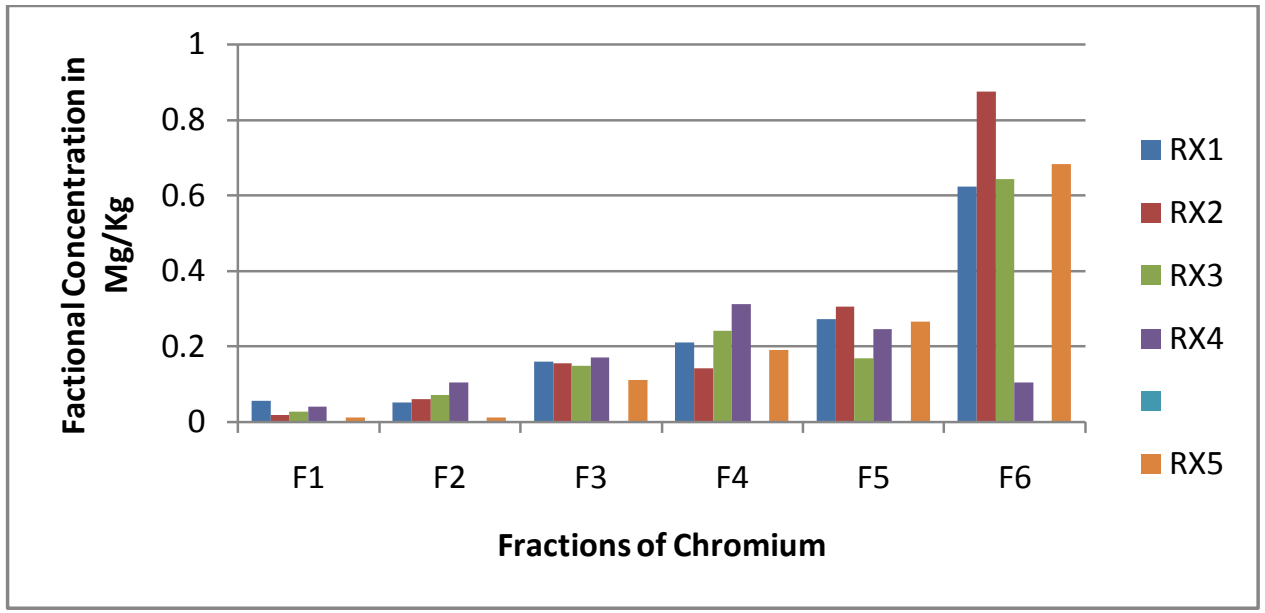

Figure 11: Fractional Concentration of $\mathrm{Cr}$ in the Various Soil Samples $(\mathrm{mg} / \mathrm{kg})$.

Figure 11, indicated that, the concentration was on the increase from F1 through F6. The observed trend in the mean concentration of $\mathrm{Cr}$ in the various fractions is F6 $>$ F5 $>$ F4 $>$ F3 $>$ F2 $>$ F1. The speciation followed a particular pattern and the \% BAF of $\mathrm{Cr}$ in all the soil samples was generally low with a mean $19.139 \%$ (Table 12).

TABLE 13: Fractional Concentration of Cd in the Various Soil Samples ( $\mathrm{mg} / \mathrm{kg})$.

\begin{tabular}{|l|l|l|l|l|l|l|l|l|l|l|}
\hline $\begin{array}{l}\text { Sample } \\
\text { code }\end{array}$ & F1 & F2 & F3 & F4 & F5 & F6 & Total & Mean & BAF & BAF \\
\hline RX1 & ND & $\begin{array}{l}0.021 \\
\pm 0.002\end{array}$ & $\begin{array}{l}0.033 \\
\pm 0.001\end{array}$ & ND & ND & $\begin{array}{l}0.042 \\
\pm 0.001\end{array}$ & 0.096 & 0.016 & 0.054 \\
\hline RX2 & ND & $\begin{array}{l}0.023 \\
\pm 0.003\end{array}$ & $\begin{array}{l}0.049 \\
\pm 0.002\end{array}$ & ND & ND & $\begin{array}{l}0.061 \\
\pm 0.004\end{array}$ & 0.133 & 0.022 & 0.072 \\
\hline RX3 & ND & $\begin{array}{l}0.026 \\
\pm 0.001\end{array}$ & $\begin{array}{l}0.050 \\
\pm 0.001\end{array}$ & ND & ND & $\begin{array}{l}0.057 \\
\pm 0.000\end{array}$ & 0.133 & 0.022 & 0.076 & 54.135 \\
\hline RX4 & ND & 0.041 & 0.034 & ND & $\begin{array}{l}0.007 \\
\pm 0.000\end{array}$ & $\begin{array}{l}0.025 \\
\pm 0.006\end{array}$ & 0.107 & 0.018 & 0.075 & 70.093 \\
\hline RX5 & ND & $\begin{array}{l} \pm 0.006 \\
\pm 0.001\end{array}$ & $\begin{array}{l}0.033 \\
\pm 0.001\end{array}$ & ND & $\begin{array}{l}0.001 \\
\pm 0.000\end{array}$ & $\begin{array}{l}0.085 \\
\pm 0.000\end{array}$ & 0.130 & 0.022 & 0.044 & 33.845 \\
\hline Total & ND & 0.122 & 0.199 & ND & 0.008 & 0.270 & 0.599 & 0.100 & 0.321 \\
\hline Mean & ND & 0.024 & 0.040 & ND & 0.002 & 0.054 & 0.120 & 0.020 & 0.064 & 271.466 \\
\hline
\end{tabular}

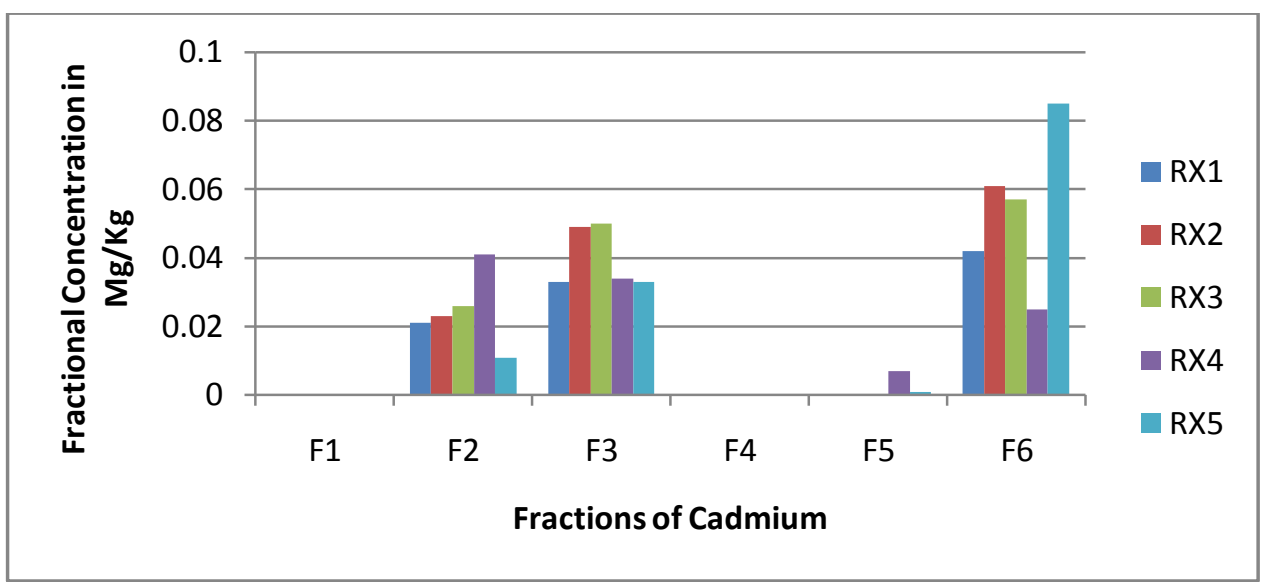

Figure 12: Fractional Concentration of Cd in the Various Soil Samples $(\mathrm{mg} / \mathrm{kg})$.

$\mathrm{Cd}$ was undetectable at the water soluble fraction and at the reducible fraction in all the samples (Table 13), so also it is in the oxidisable fraction except on samples RX4 and RX5. The trend in the mean concentration of Cd was F6 > F3 > F2 > F5 > F4 > F1. Figure 27, indicated that the speciation was more in the residual fraction followed by the carbonate fraction. Even though $\mathrm{Cd}$ was undetectable at the water soluble fraction, its \% BAF was still high with a mean of $54.293 \%$, suggesting that $\mathrm{Cd}$ is potentially bioavailable in the studied area. 
TABLE 14: Percentage Bioavailability of Metal Concentration in the Soil Samples.

\begin{tabular}{|l|l|l|l|l|l|l|l|l|l|l|}
\hline $\begin{array}{l}\text { Sample } \\
\text { code }\end{array}$ & $\mathrm{Cu}$ & $\mathrm{Ca}$ & $\mathrm{Mn}$ & $\mathrm{Pb}$ & $\mathrm{Ni}$ & $\mathrm{Fe}$ & $\mathrm{Co}$ & $\mathrm{Zn}$ & $\mathrm{Cr}$ & $\mathrm{Cd}$ \\
\hline RX1 & 38.909 & 58.072 & 31.707 & 80.080 & 39.112 & 37.744 & 44.968 & 19.342 & 19.357 & 56.250 \\
\hline RX2 & 59.311 & 46.107 & 30.987 & 26.918 & 31.396 & 16.944 & 27.934 & 4.842 & 14.948 & 54.135 \\
\hline RX3 & 34.551 & 65.186 & 29.147 & 49.553 & 39.228 & 4.531 & 92.097 & 12.734 & 18.856 & 57.143 \\
\hline RX4 & 36.253 & 18.008 & 36.939 & 8.364 & 65.831 & 15.115 & 69.519 & 47.020 & 32.202 & 70.093 \\
\hline RX5 & 30.668 & 63.075 & 36.921 & 81.422 & 54.380 & 37.409 & 26.344 & 7.941 & 10.331 & 33.845 \\
\hline GT & 199.692 & 250.448 & 165.701 & 246.337 & 229.947 & 111.743 & 260.862 & 91.879 & 95.694 & 271.466 \\
\hline GM & 39.938 & 50.090 & 33.140 & 49.267 & 45.989 & 22.349 & 52.172 & 18.376 & 19.139 & 54.293 \\
\hline
\end{tabular}

GT $=$ Ground Total and GM $=$ Ground Mean

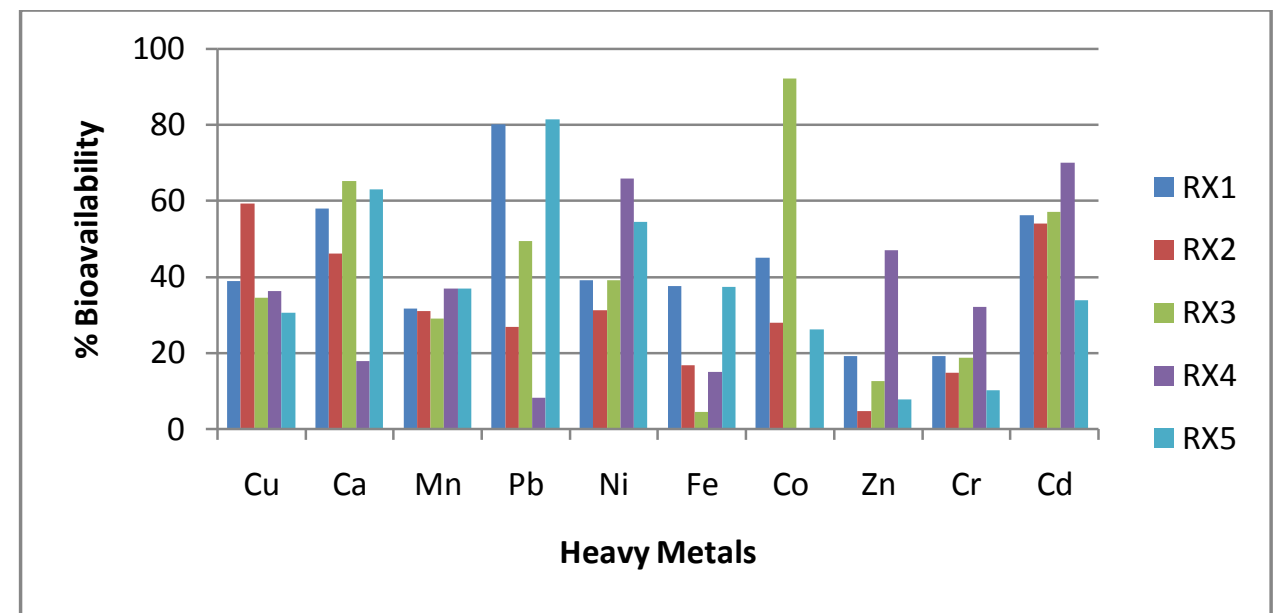

Figure 13: Percentage Bioavailability of Metal Concentration in the soil Samples.

We observed that $\mathrm{Cd}$ is the most available metal for organism's uptake in the studied area since it had the highest \%BAF in the soil samples (Erwin, 2006). The trends in the percentage bioavailability of the various heavy metals are as follows: for $\mathrm{RX} 1$ it was $\mathrm{Pb}>\mathrm{Ca}>\mathrm{Cd}>\mathrm{Co}>\mathrm{Ni}>\mathrm{Cu}>\mathrm{Fe}>\mathrm{Mn}>\mathrm{Cr}>\mathrm{Zn}$, and for $\mathrm{RX} 2$, it was $-\mathrm{Cu}>\mathrm{Cd}>\mathrm{Ca}>\mathrm{Ni}>\mathrm{Mn}>\mathrm{Co}>\mathrm{Pb}>\mathrm{Fe}>\mathrm{Cr}>\mathrm{Zn}$, for $\mathrm{RX3}$, it was $\mathrm{Co}>\mathrm{Ca}>\mathrm{Cd}>\mathrm{Pb}>\mathrm{Ni}>\mathrm{Cu}>$ $\mathrm{Mn}>\mathrm{Cr}>\mathrm{Zn}>\mathrm{Fe}$, while for RX4 and RX5 it was $\mathrm{Cd}>\mathrm{Co}>\mathrm{Ni}>\mathrm{Zn}>\mathrm{Mn}>\mathrm{Cu}>\mathrm{Cr}>\mathrm{Ca}>\mathrm{Fe}>\mathrm{Pb}$, and $\mathrm{Pb}>\mathrm{Ca}>\mathrm{Ni}>\mathrm{Fe}>\mathrm{Mn}>\mathrm{Cd}>\mathrm{Cu}>\mathrm{Co}>\mathrm{Cr}>\mathrm{Zn}$ respectively.

It can be inferred from the trends that $\mathrm{Zn}$ had the least bioavailable fractions in most of the soil samples. Cd recorded the highest ground mean concentration (54.213\%) and the least was found in Zinc $(18.376 \%)$. The trend of the ground mean percentage bioavailability for the various heavy metals was $\mathrm{Cd}>\mathrm{Co}>$ $\mathrm{Ca}>\mathrm{Pb}>\mathrm{Ni}>\mathrm{Cu}>\mathrm{Mn}>\mathrm{Fe}>\mathrm{Cr}>\mathrm{Zn}$.

Correlation analysis was conducted to determine the extent of the relationship among metal fractions and among metals in the soils over the studied area. A probability of less than $5 \%(\mathrm{P}>0.05)$ was considered to be statistically significant.

$\mathbf{C u}$ - In the correlation of various fractions of $\mathrm{Cu}$ in the soil samples, we observed that there was no significant difference in the result at $95 \%$ confidence interval in all the fractions. Ca - There was no significant difference in the correlation of the various fractions of $\mathrm{Ca}$ in the soil samples. Mn - The correlations of the various fractions of manganese in the soil samples indicated that there was no significance difference. $\mathbf{P b}-$ There was a positive significance difference in the correlation between the reducible fraction and the oxidizable fraction of the soil samples. Ni - In the correlation of various fractions of nickel in the soil samples, there was positive significance difference in the carbonate and the reducible fractions. Fe - The correlation of the oxidizable fraction of $\mathrm{Fe}$ and the water soluble fraction of $\mathrm{Fe}$ was positively significant in the soil samples and between the carbonate and the oxidisable fractions but, negatively significant between the water soluble and the oxidisable fractions. Co - The correlation of the various fractions of Co in the soil samples shows a positive significance difference between the exchangeable fraction and the water soluble fraction, $\mathbf{Z n}-$ The Correlation of zinc fractions in the soil sample shows that it was positively significant between their oxidisable fractions. The correlation also showed a positive significant difference between carbonate and exchangeable, oxidisable and exchangeable, oxidisable and carbonate and between reducible and the residual fractions. The T-test indicates no significance in all. $\mathbf{C r}$ - in the correlations of $\mathrm{Cr}$, there was positive significant difference between the residual and the water soluble fraction in the soil samples. Cd - The T-test showed a positive relationship between all the fractions of the soil samples. 


\section{Conclusion}

The ANOVA indicates that $\mathrm{Ca}$ had a significant mean difference in the water soluble fractions of the soil samples and so also it is in the exchangeable fractions of the soil samples. Fe was also significance in the exchangeable fraction. But in the carbonate bound, reducible, oxidisable and residual fractions, it was only $\mathrm{Fe}$ that had a significance mean difference at $95 \%$ confidence interval in the soil samples. This suggests that there are several location (sites) having greater $\mathrm{Ca}$ and $\mathrm{Fe}$ concentration and the soil have been contaminated more severely by these metals, Though $\mathrm{Ca}$ and $\mathrm{Fe}$ are among the micronutrient elements. This means that the human activities in and around the area have significant effects on the level of almost all metals in the soils over this studied area. The speciation of $\mathrm{Ca}$ was different as the concentration was evenly distributed in all the fractions of the soil samples and speciation of $\mathrm{Cu}$ showed higher concentration in the water soluble fraction in the soil samples.

Further work is recommended in the area with reference to the heavy metal speciation some centimetres (about $30 \mathrm{~cm}$ ) below the soil surface so as to determine the solubility as well as the bioavailability of these metals.

\section{References}

[1] L.E. Bennett, J.L. Burkhead, K.L. Hale, N. Terry, M. Pylons, and Pilon-smits, Analysis of Transgenic Indian mustard Plants for Phytoremediation of Metals Contaminated Mine Tailings. J. of Environmental Quality, 32, 2003, 432-440.

[2] E.U. Ikhuoria, and F.E. Okieimen, Scavenging Cadium, copper, lead, Nickel and Zinc ions from aqueous solution by modified cellulosic sorbent. Intl. J. of Environ. Studies. 57(4), (2000), 4010.

[3] J.O. Nriagu, The biochemistry of $\mathrm{Pb}$ in the environment. (Elsevier, Amsterdam 2000).

[4] United States Protection Agency Reports, Introduction to phytoremediation. 2000, EPA 600/R.99/107.

[5] S. Zhen-Guo, L. Xian-Dong, W. Chun-Chun, Ch. Huai-Man and Ch. Hong, Lead Phytoextraction from contaminated soil with high biomass plant species. J. Environ. Qual., 31, 2002, 1893-1900.

[6] M. Pueyo, and E. Sastre, Prediction of trace element mobility in contaminated soils by sequential extraction. Journal of Environmental Quality Spain, 32, 2003, 2054-2066.

[7] J.J.K. Erwin, Chemical Speciation and Bioavailability of Heavy Metals in Soil and Surface Water. (Wageningen University, Wageningen, Netherlands. 2006), p.10.

[8] M.A. Nwachukwu, H. Feng, and J. Alinnor, Assessment of heavy metal pollution in soil and their implication within and around mechanic villages. Intl. J. Environ. Sci. Tech., 7(2), 2010, 347-358.

[9] P.C. Onianwa, O.M. Jaiyeola and R.N. Egekenze, Heavy metal contamination of topsoil in the vicinities of auto repair workshop, gas stations and motor parks in Nigeria city. Toxicol. Environ. Chem., 84(1-4), 2001, 33-39.

[10] P. E. Omuku, P. A. C. Okoye, A. C Okoye,. and H. A. Onwumelu, Partitioning of Selected Heavy Metals in Nnewi, A busy city in Anambra State, Nigeria. J. Int. Env. Application and Sci. Turkey 5(5), 2010, 713-719.

[11] A.M. Ure, and C.M. Davidson, Chemical Speciation in The Environment. Blackie, Glasgow. 2001, $265-321$.

[12] J.O. Duruibe, M.O.C Ogwuegbu and J.N. Egwuruegwu, Heavy Metal Pollution and Human Biotoxic Effects. International Journal of Physical Sciences, 2(5), 2007, 112-118.

[13] A., Tessier, P.G.C Campbell,. and M. Blsson. Sequential Extraction Procedure for the Speciation of Particulate Trace Metals. Analytical Chemistry, 51(7), 1979, 844-845. 